\title{
Performance of juvenile mojarra supplied with feed containing varying levels of crude protein
}

\author{
Desempenho de juvenil de carapeba alimentado com rações contendo \\ diferentes níveis de proteína bruta
}

\author{
Ricardo Henrique Bastos de Souza', Francisco Oliveira de Magalhães Júnior², Filipe dos Santos Cipriano³, \\ Kauana Santos Lima ${ }^{4}$, Sylvia Sanae Takishita², Luís Gustavo Tavares Braga² ${ }^{2 *}$
}

\author{
${ }^{1}$ Fundação Universidade Federal de Rondônia/UNIR, Porto Velho, RO, Brasil \\ Universidade Estadual de Santa Cruz/UESC, Departamento de Ciências Agrárias e Ambientais/DCAA, Ilhéus, BA, Brasil \\ ${ }^{3}$ Universidade Federal de Minas Gerais/UFMG, Belo Horizonte, MG, Brasil \\ ${ }^{4}$ Universidade Federal da Bahia/UFBA, Salvador, BA, Brasil \\ *Corresponding author: Igtbraga@gmail.com \\ Received in august 25, 2015 and approved in october 30, 2015
}

\begin{abstract}
The growth of the Brazilian aquaculture has stimulated the development of the productive chain of native species, including marine environment. The objective of this study was to evaluate the growth performance of juvenile mojarra fish (Diapterus rhombeus) fed diets containing different concentrations of crude protein $\left(32,36,40\right.$ and $\left.44 \mathrm{~g} 100 \mathrm{~g}^{-1}\right)$. The 80 juvenile mojarra $(7.2 \pm 1.5 \mathrm{~g})$ were kept in 16 circular tanks $(150 \mathrm{~L})$. The study design used was completely randomized with four treatments and four repetitions. The fish were fed four times a day. At the end of the experiment (60 days) the final weight, feed intake, weight gain (WG), feed:gain ratio (FGR), protein efficiency rate (PER), energy efficiency rate, specific growth, survival rate and, body composition were evaluated. It was verified significant effect of

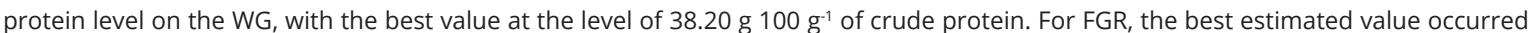

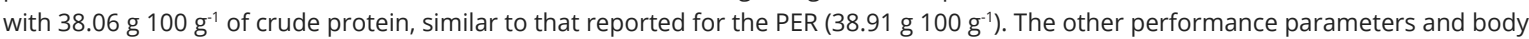

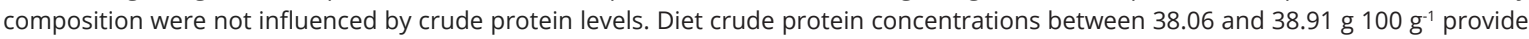
the best performance indices for juvenile mojarra.
\end{abstract}

Index terms: Fish farming; fish nutrition; mariculture; marine environment; Diapterus rhombeus.

\begin{abstract}
RESUMO
O crescimento da aquicultura brasileira tem estimulado o desenvolvimento da cadeia produtiva de espécies nativas, incluindo de ambiente marinho. Objetivou-se, neste estudo, avaliar o desempenho dos juvenis de carapeba (Diapterus rhombeus) alimentados com rações contendo diferentes concentrações de proteína bruta (32, 36, 40 e 44 g 100 g-1), caracterizando um delineamento inteiramente casualizado, com quatro tratamentos e quatro repetições. Foram distribuídos 80 juvenis $(7,2 \pm 1,5 \mathrm{~g})$ de carapeba em 16 tanques circulares (150 L). Os peixes foram alimentados quatro vezes ao dia. Após 60 dias, foram avaliados o peso final, o consumo de ração, o ganho de peso (GP), a conversão alimentar (CA), a taxa de eficiência proteica (TEP), a taxa de eficiência energética, o crescimento específico, a taxa de sobrevivência e a composição corporal dos peixes. Verificou-se efeito significativo do nível de proteína com o melhor valor de GP obtido com 38,20 g $100 \mathrm{~g}^{-1}$ de proteína bruta. Para a CA, o melhor valor estimado ocorreu com 38,06 g $100 \mathrm{~g}^{-1}$ de proteína bruta, próximo

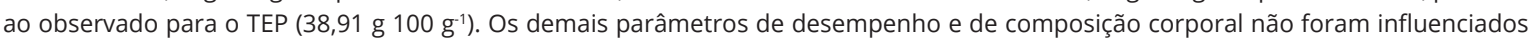
pelos níveis de proteína bruta. As concentrações de proteína bruta na dieta entre 38,06 e 38,91 g 100 g-1 promovem os melhores índices de desempenho de juvenis de carapeba.
\end{abstract}

Termos para indexação: Piscicultura; nutrição de peixe; maricultura; ambiente marinho; Diapterus rhombeus.

\section{INTRODUCTION}

Protein is the costliest part of a feed's nutritional composition and determining the minimum concentration of viable protein in feed for fish is therefore of great importance (Mabrouk; Nour, 2011). Another important factor to be considered is that a feed that is better adjusted to the needs of the species could generate fewer pollutants because the animals will more efficiently use the nutrients contained in the feed, thereby eliminating excess nutrient expulsion in the water (Cyrino et al. 2010).

Dose-response studies may be performed in which the protein requirement of a species is interpreted as the minimum level necessary to meet amino acid needs and promote maximum growth (National Research CouncilNrc, 2011). However, it is important to consider factors 
that may influence the protein requirements of fish species, such as water temperature, feeding rate, fish size, protein quality, and the involvement of non-protein energy sources (Kaushik et al., 2004; Moura et al., 2007; Bomfim; Lanna; Donzele, 2008).

The mojarra (Diapterus rhombeus) belonging to the Gerreidae family are found in coastal environments of the north-eastern, southern and south-eastern regions of Brazil. It is a fish that lives in tropical and subtropical waters and feeds on algae and small invertebrates. It can be found from the open seas up to the salt-water regions near estuaries (Aguirre-Léon; Díaz-Ruiz 2006; Silva et al. 2011; Elliff et al., 2013).

Although the mojarra is a native species and has advantageous characteristics: it has excellent meat quality, is euryhaline, is omnivorous, has a small head in relation to its body, is widely ranging and is found in schools. Few studies have been performed on this species' nutritional requirements or on techniques for its production in captivity (Aguirre-Léon; Díaz-Ruiz, 2006).

Considering the importance of discovering new species with potential for marine fish farming and the importance of protein in fish growth and development, the objective of this study was to evaluate the performance of juvenile mojarra (Diapterus rhombeus) fed diets with varying levels of crude protein.

\section{MATERIAL AND METHODS}

The experiment was performed at the Fish Food and Nutrition Laboratory (AQUANUT) at Santa Cruz State University, Ilhéus, Bahia, Brazil (14 47' $20^{\prime \prime} \mathrm{S}$ e $39^{\circ} 02^{\prime} 58^{\prime \prime} \mathrm{W}$ ), and it lasted 60 days. Juvenile mojarra (Diapterus rhombeus), from the Camamu bay estuary in the municipality of Ituberá, Bahia, Brazil (1343'13.9' S and $39^{\circ} 46.7^{\prime} 07^{\prime \prime} \mathrm{W}$ ), were collected with the support of local fishermen, using a 50 x 2-meter trawl with 12-mm mesh, dip nets, canoe and supporting vessels. Collection occurred mainly between August and November due to the fact that this period provided the greatest abundance of juveniles at the collection site.

Physical and chemical variables of the water at the collection site were measured using the multi-parameter YSI Professional Plus device so that the same conditions could be reproduced in laboratories where the fish would go through adaptation and experimentation. The average figures obtained for the physical and chemical parameters and standard deviation were as follows: temperature, $26.7 \pm 0.6{ }^{\circ} \mathrm{C}$; dissolved oxygen, $8.9 \pm 1.2 \mathrm{mg} \mathrm{L}^{-1}$; $\mathrm{pH}$, $7.4 \pm 0.4$; and salinity, $1.8 \pm 20$ ppt.
Fish adaptation was performed in two periods. The first adaptation period occurred after capture and involved transferring the fish to a support laboratory near the collection location. The aim of the first adaptation period was to minimize the stress caused by capture and to begin conditioning the fish to the confinement conditions and feed management before being transported to the definitive experimental laboratory. To this end, the fish were kept in 310-L fiberglass boxes with an available volume density of 0.32 fish per $L$ of water; these tanks were provided with constant aeration and biological filtration where the subjects were fed freshly chopped fish fillet (Micropogonias furnieri) four times a day for 15 days.

The second adaptation period occurred after the mojarra were moved in a transportation box $(500 \mathrm{~L})$ with an artificial oxygenation system to AQUANUT, where they went though adaptation to definitive laboratory conditions and routine management for a period of fifteen days. The fish were distributed into 110-L tanks with available volume densities of 0.073 fish per $\mathrm{L}$ of water and fed four times a day. During the second period of adaptation, the chopped fish fillet feed was gradually replaced with pelletized feed ( $2 \mathrm{~mm}$ in diameter, containing $48{\mathrm{~g} 100 \mathrm{~g}^{-1}}^{-1}$ of crude protein and $4044 \mathrm{kcal} \mathrm{kg}^{-1}$ of gross energy); by the 15th day, the natural feed had been totally replaced by the pelletized feed, completing the feed training. After the feed training period, the fish that appeared to have adapted to the process continued to be fed with only the pelletized feed. However, most of the fish had to repeat the feed training period.

For performance analysis, 80 juvenile mojarra were used with an average weight of $7.25 \pm 0.99 \mathrm{~g}$ and were quantitatively distributed in a completely randomized study design with four treatments and four repetitions in 16 fiberglass tanks with $110 \mathrm{~L}$ of available volume. Five juveniles were stored per experimental unit connected by a closed circulation system. Mechanical and biological filtration was provided through the use of gravel, expanded clay and bivalve shells as substrates and constant aeration was supplied with a radial blower (Mod. CV-101R, VENTBRAS Ind. Eletrometalúrgica Ltda, SP, Brazil).

The photoperiod was 12 hours of light. Physical and chemical variables such as water temperature, $\mathrm{pH}$, dissolved oxygen and salinity were measured daily with the multi-parameter YSI Professional Plus device, which provided mean values of $25.75 \pm 0.8^{\circ} \mathrm{C}, 7.49 \pm 0.3,8.25 \pm 1.2$ $\mathrm{mg} \mathrm{L}^{-1}$, and $21.9 \pm 1.1 \mathrm{ppt}$, respectively.

The aquariums were cleaned by weekly siphoning after the last feeding in order to remove faeces and possible feed remnants during the adjustment and trial periods. 
Water replacement in the system was performed based on a salinity measurement: fresh water was added when the salinity was greater than $22 \mathrm{ppt}$, and saltwater was added when the salinity was below 20 ppt.

The dietary plan consisted of daily at four time points $(08: 00,10: 00,14: 00$ and 16:00), with a continuous supply of feed until there was apparent satiation. Biometrics were performed at the beginning and at the end of the trial period, after the fish were subjected to a 24-hour fast to allow for intestinal evacuation before being weighed. During the trial period, fish mortality was checked daily, and the dead fish were weighed so as to adjust the experimental unit's consumption calculation.

In order to define crude protein profile from experimental feed, this study sought to maintain an approximately consistent relationship between lysine, threonine and methionine+cystine and with crude protein obtained through the body composition of analysed fish. The carcass's amino acid composition was determined by the company Ajinomoto do Brazil Indústria e Comércio de Alimentos Ltda (Table 1).

The experimental diets were formulated to contain four different protein concentrations: $32,36,40$ and $44 \mathrm{~g}$ $100 \mathrm{~g}^{-1}$ (Table 2).

Regarding the feed production, the ingredients were ground down using a knife grinder with a 0.5 $\mathrm{mm}$ sieve, then weighed on semi-analytical scales and manually mixed with preheated filtered water at $55^{\circ} \mathrm{C}$, thereby increasing the gelatinizing effect on the starch and providing a greater stability of the feed in the aquatic environment (Ferrari et al., 2004). Subsequently, the feed were pelleted in a grinder, resulting in pellets of approximately $2 \mathrm{~mm}$ in average diameter, and then dried in a recirculation oven at $60^{\circ} \mathrm{C}$ for 24 hours. At the end of the process, the feed was stored in a refrigerator at $-4{ }^{\circ} \mathrm{C}$ until the start of the experiment.

The bromatological composition analyses of the feed and the fish carcass (dry matter, crude protein and gross energy) were performed at the Animal Nutrition Laboratory and the Fish Food and Nutrition Laboratory at the State University of Santa Cruz. The body composition analysis of the fish was performed at the beginning and the end of the experiment. At the beginning, three samples of five fish each were analysed and, at the end of the experiment, all surviving fish in each experimental unit constituted a sample to be analysed. The sacrificed fish were previously anesthetized with benzocaine $\left(20 \mathrm{~g} \mathrm{~L}^{-1}\right)$ and immersed in ice. Subsequently, the whole fish were pre-dried in a circulation oven at $65^{\circ} \mathrm{C}$ for 72 hours and grinded in a ball mill for analysis of dry matter, crude protein, gross energy and ethereal extract in accordance with the methodology described in "Official Methods of Analysis of the Association of Official Analytical Chemists" (Association of Official Analytical ChemistsAOAC, 2005).

From data obtained during the biometrics performed at the beginning and at the end of the experiment and from the body composition analysis, performance indices and nutrient utilization were calculated as follows:

Feed Consumption (g): Consumption $=$ Weighed Feed at the beginning - leftover feed

Weight gain $(\mathrm{g})$ : $\mathrm{WG}=$ Final Weight - Initial Weight

Feed:gain ratio (non-dimensional): FGR = $\left(\frac{\text { Feed Consumed }}{\text { WG }}\right)$

Specific growth rate $(\%)$ : SGR $=$

$\left[100 * \frac{\text { (In Final Weight }- \text { In Inicial Weight }}{\text { Time }}\right]$

Table 1: Amino acid composition and relation considering crude protein concentration of mojarra carcass and diets as reference.

\begin{tabular}{cccccc}
\hline \multirow{2}{*}{ Amino acids } & \multicolumn{5}{c}{ Concentration of amino acids in the carcass and diets $\left({\left.\mathrm{g} 100 \mathrm{~g}^{-1}\right)}^{-}\right.$} \\
\cline { 2 - 5 } & Carcass & 32 & 36 & 40 & 44 \\
\hline Lysine & 3.30 & 1.81 & 2.12 & 2.42 & 2.73 \\
Threonine & 2.10 & 1.18 & 1.37 & 1.57 & 1.76 \\
Methionine+cystine & 1.91 & 1.34 & 1.45 & 1.55 & 1.66 \\
\hline \multicolumn{6}{c}{ Ratio of amino acids in the carcass and diets } \\
\hline Lysine & 5.87 & 5.66 & 5.88 & 6.06 & 6.20 \\
Threonine & 3.74 & 3.69 & 3.81 & 3.92 & 4.00 \\
Methionine+cystine & 3.39 & 3.39 & 3.38 & 3.38 & 3.39 \\
\hline
\end{tabular}


Survival $(\%)=\left(\frac{\text { Final N Individuals }}{\text { Starting N Individuals }}\right) \times 100$

Protein efficiency rate (\%):

$\mathrm{PER}=\left[\frac{\text { (Final Body Protein }- \text { Starting Body Protein }}{\text { Protein Consumed }}\right] \times 100$

Energy efficiency rate (\%):

$\mathrm{EER}=\left[\frac{\text { (Final Body Energy }- \text { Starting Body Energy) }}{\text { Consumed Energy }}\right] \times 100$

All data were tested for normality and homogeneity; subsequently, the data were subjected to regression analysis, and the 95\% adopted degree of significance was used to verify the relationship between the variables. Statistical analyses were performed using the R Development Core Team software (2011).

\section{RESULTS AND DISCUSSION}

Fish survival rates ranged from 85 to $100 \%$ among the treatments, although no significant effect was observed in the protein level regarding the parameter in the experimental conditions used. Similarly, the elevation of the protein concentration in the feed did not influence the total feed intake of the mojarra, which ranged from $13.8 \pm 0.2$ to $16.9 \pm 0.9 \mathrm{~g}$ of feed.

Table 2: Ingredients and proximate composition of experimental diets for juvenile mojarra, Diapterus rhombeus.

\begin{tabular}{|c|c|c|c|c|}
\hline \multirow{2}{*}{ Ingredient } & \multicolumn{4}{|c|}{ Concentration of protein in diets $\left(\mathrm{g}^{\left.100 \mathrm{~g}^{-1}\right)}\right.$} \\
\hline & 32 & 36 & 40 & 44 \\
\hline Soybean meal - 45\% CP & 21.49 & 29.93 & 38.38 & 46.82 \\
\hline Fish meal - 55\% CP & 16.00 & 21.33 & 26.67 & 32.00 \\
\hline Meat and bone meal - 45\% CP & 16.00 & 13.47 & 10.93 & 8.40 \\
\hline Wheat bran & 18.00 & 13.67 & 9.33 & 5.00 \\
\hline Corn gluten meal - 22\% CP & 15.89 & 11.59 & 7.30 & 3.00 \\
\hline Corn meal & 5.00 & 3.93 & 2.87 & 1.80 \\
\hline Vitamin - mineral pre-mixture ${ }^{1}$ & 1.50 & 1.50 & 1.50 & 1.50 \\
\hline Corn starch & 5.12 & 3.61 & 2.11 & 0.60 \\
\hline Common salt & 0.50 & 0.50 & 0.50 & 0.50 \\
\hline DL- Methionine & 0.20 & 0,19 & 0.19 & 0.18 \\
\hline L- Lysine HCL & 0.10 & 0.07 & 0.03 & 0 \\
\hline $\mathrm{BHT}^{2}$ & 0.20 & 0.20 & 0.20 & 0.20 \\
\hline Total & 100 & 100 & 100 & 100 \\
\hline \multicolumn{5}{|c|}{ Calculated composition $\left(\mathrm{g}_{\left.100 \mathrm{~g}^{-1}\right)}\right.$} \\
\hline Gross energy (kcal kg-1) & 3914 & 3953 & 3994 & 4033 \\
\hline Crude protein ( $\left.\mathrm{g} 100 \mathrm{~g}^{-1}\right)$ & 318.1 & 357.9 & 397.7 & 437.6 \\
\hline Ether extract ( $\left(\mathrm{g} 100 \mathrm{~g}^{-1}\right)$ & 4.61 & 4.75 & 4.88 & 5.02 \\
\hline Energy-protein ratio $\left(\mathrm{Kcal} \mathrm{g}^{-1}\right)$ & 12.3 & 11.0 & 10.0 & 9.2 \\
\hline Calcium $\left(\mathrm{g} 100 \mathrm{~g}^{-1}\right)$ & 1.40 & 1.63 & 1.70 & 1.72 \\
\hline Phosphorus (g $100 \mathrm{~g}^{-1}$ ) & 0.73 & 0.85 & 0.86 & 0.88 \\
\hline Calcium-phosphorus ratio & 1.92 & 1.92 & 1.98 & 1.95 \\
\hline
\end{tabular}

${ }^{1}$ Composition/kg of product: vit. $\mathrm{A}=6,000,000 \mathrm{Ul}$; vit. $\mathrm{D} 3=2,250,000 \mathrm{Ul}$; vit. $\mathrm{E}=75,000 \mathrm{mg}$; vit. $\mathrm{K3}=3,000 \mathrm{mg}$; vit. thiamine= $5,000 \mathrm{mg}$; riboflavin $=10,000 \mathrm{mg}$; vit. pyridoxine $=8,000 \mathrm{mg}$; biotin = 2,000 mg; vit. C = 192,500 mg; niacin = 30,000 mg; folic acid = 3,000 mg; Fe = 100,000 mg; Cu = 600 mg; Mn = 60,000 mg; Zn = 150,000 mg; I = 4,500 mg; Cu = 15,000 mg; Co = 2,000mg; Se $=400 \mathrm{mg} .{ }^{2} \mathrm{BHT}=$ Butyl-hydroxyl-toluene. 
Furthermore, no significant effect of the treatments was observed on the energy efficiency rate that ranged from $11.7 \pm 4.5$ to $18.1 \pm 3.4 \%$. There was no significant effect of increased levels of protein in the feed on the specific growth rate of the fish, which ranged from $0.5 \pm 0.1$ to $0.9 \pm 0.2 \%$.

Regarding the other analysed variables (final weight, weight gain, feed:gain ratio and protein efficiency rate), it was found that the increase in the levels of crude protein in the feed had a significant quadratic effect, and that with

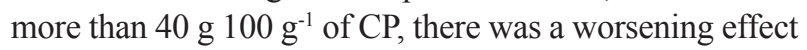
for all the variables mentioned above (Table 3 ).

A significant quadratic effect was also observed in the levels of crude protein on juvenile mojarra weight gain, which increased up to the level of $38.20{\mathrm{~g} 100 \mathrm{~g}^{-1}}^{-1}$ of CP (Figure 1).

These results indicate that either an excess or deficiency of protein may have an effect on this species' weight gain. Supplying dietary protein below the species' needs may compromise weight gain because the nutrient is the main component for the growth and development of the fish and it provides amino acids that are continuously used in the process of body protein synthesis and degradation (Millward, 1989). The positive correlation between the amount of digestible protein in the diet and weight gain, suggested that the amount and quality protein influence the growth rate of the fish (Sampaio; Kubitza; Cyrino, 2000).

Fish use approximately $50 \%$ of the feed protein as an energy source; in this way, it is expected that a deficiency of protein will have a larger detrimental effect on weight gain than in situations of excess protein (Wilson, 2003). However, researchers working with different fish species observed that excess protein can cause reduced weight gain. Sampaio, Kubitza and Cyrino (2000), when comparing levels of crude protein in tucunaré fingerlings (Cichla SP.) and Bomfim, Lanna and Donzele (2008), while evaluating Nile tilapia fingerlings (Oreochromis niloticus) observed a reduction in fish weight gain with the higher protein levels tested.

Another factor that can justify the fall in weight

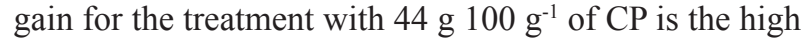
inclusion of soybean meal in feed production, since the ingredient has a limited level of inclusion in the feed due to the possibility of it containing anti-nutritional factors. Among the substances that produce adverse effects on the performance of the animals include protease inhibitors that can directly influence the use of nutrients in the diet being capable of binding to pancreatic proteolytic enzymes (trypsin and chymotrypsin), inactivating them and consequently reducing the growth rate in animals due to the diminished use of dietary protein (Stech; Carneiro; Carvalho, 2010).

According to Refstie, Storebakken and Roem (1998), the negative effect of these anti-nutritional factors led to lower levels of consumption and weight gain for Atlantic salmon (Salmo salar). The same effect was observed in silver catfish fingerlings (Rhamdia quelen) by Lazzari et al. (2008). The negative influence on feed:gain ratio and protein efficiency rate, assigned to the trypsin inhibitor present in the feed, was also observed by Refstie, Helland and Storebakken (1997) in rainbow trout (Oncorhynchus mykiss).

Table 3: Average values of performance parameters in mojarra (Diapterus rhombeus) fed with different crude protein levels in the diet.

\begin{tabular}{crrrrl}
\hline \multirow{2}{*}{ Variable } & \multicolumn{4}{c}{ Concentration of protein in diets $\left(\mathrm{g} 100 \mathrm{~g}^{-1}\right)$} & \multirow{2}{*}{$p$-value } \\
\cline { 2 - 5 } & \multicolumn{1}{c}{32} & \multicolumn{1}{c}{36} & \multicolumn{1}{c}{40} & \multicolumn{1}{c}{44} & \\
\hline Initial weight (g) & $7.2 \pm 0.9$ & $7.2 \pm 0.9$ & $7.2 \pm 0.9$ & $7.2 \pm 0.9$ & 1.00 \\
Final weight (g)* & $9.9 \pm 0.8$ & $11.6 \pm 2.2$ & $11.9 \pm 1.8$ & $9.9 \pm 0.9$ & 0.03 \\
Feed intake (g) & $13.8 \pm 0.2$ & $16.8 \pm 3.8$ & $16.9 \pm 0.9$ & $15.6 \pm 0.2$ & 0.13 \\
Weight gain (g)* & $2.7 \pm 0.8$ & $4.3 \pm 1.0$ & $4.8 \pm 1.1$ & $2.7 \pm 0.7$ & 0.01 \\
Feed:gain ratio* & $5.5 \pm 0.9$ & $3.6 \pm 0.6$ & $4.8 \pm 1.0$ & $5.3 \pm 1.2$ & 0.06 \\
Specific growth rate (\%) & $0.5 \pm 0.1$ & $0.8 \pm 0.2$ & $0.9 \pm 0.2$ & $0.5 \pm 0.1$ & 0.28 \\
Protein efficiency rate (\%)* & $2.3 \pm 1.1$ & $7.0 \pm 2.8$ & $5.1 \pm 2.5$ & $4.5 \pm 2.5$ & 0.08 \\
Energy efficiency rate (\%) & $13.4 \pm 4.8$ & $15.6 \pm 5.7$ & $18.1 \pm 3.4$ & $11.7 \pm 4.5$ & 0.28 \\
Survival (\%) & 100 & $85 \pm 19.1$ & $95 \pm 10,0$ & 100 & 0.70 \\
\hline
\end{tabular}

* Quadratic effect. 


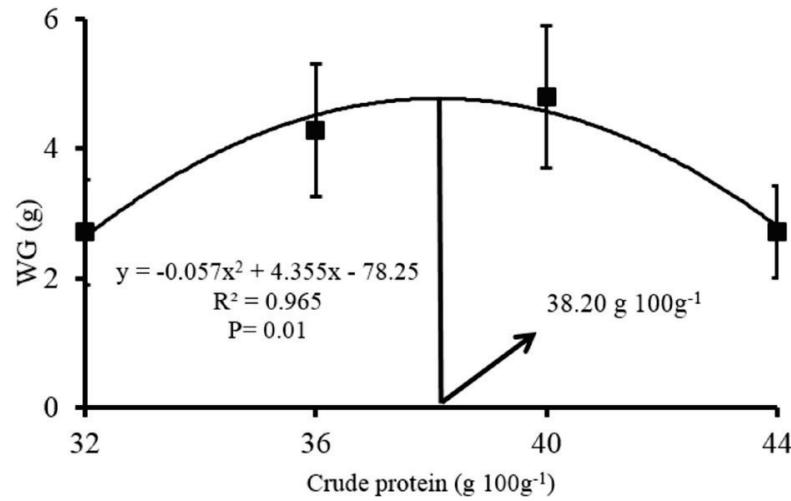

Figure 1: Polynomial regression of mean weight gain (WG) in juvenile mojarra (Diapterus rhombeus) fed with different crude protein levels in the diet.

In this way, the results for final weight, protein efficiency rate, weight gain and feed:gain ratio in mojarra fed with a higher protein content reinforces the assertion that high levels of vegetable protein in fish diets can cause a reduction in growth and a lowering in feed efficiency. It is important to consider that mojarra in their natural environment feed on invertebrates, plants and also, to a lesser extent, fish. However, the staple food of their diet are polychaetes present in more than $75 \%$ of individuals analysed and occupying, on average, $50 \%$ of the fish's stomach volume (Chaves; Otto, 1998). It is possible that the mojarra has limited ability to digest high levels of proteins from a vegetable source.

In contrast to the worsening performance of fish observed from the $40 \mathrm{~g}$. $100 \mathrm{~g}^{-1}$ level, results from which an optimal level of protein resulted in an improvement in weight gain, as observed by Sá and Fracalossi (2002) when working with piracanjuba (B. orbigyanus), by Fernandes, Carneiro and Sakamura (2001) in pacu juveniles ( $P$. mesopotamicus), by Cotan, Lanna and Bomfim (2006) in two spot astyanax fingerlings (Astyanax bimaculatus) and by Wang (2013) in pompano (Trachinotus ovatus).

Other authors did not observe a detrimental effect from higher levels of protein on weight gain for some species, as in the cases of Vidal Junior (1998), who tested levels of crude protein in tambaqui (Colossoma macropomum) at stages from 30 to $250 \mathrm{~g}$, and Signor et al. (2004), who assessed crude protein requirement in silver catfish fingerlings (Rhamdia quelen).

There was a quadratic effect of the treatments on the feed:gain ratio, which reduced the estimated level to

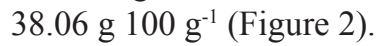

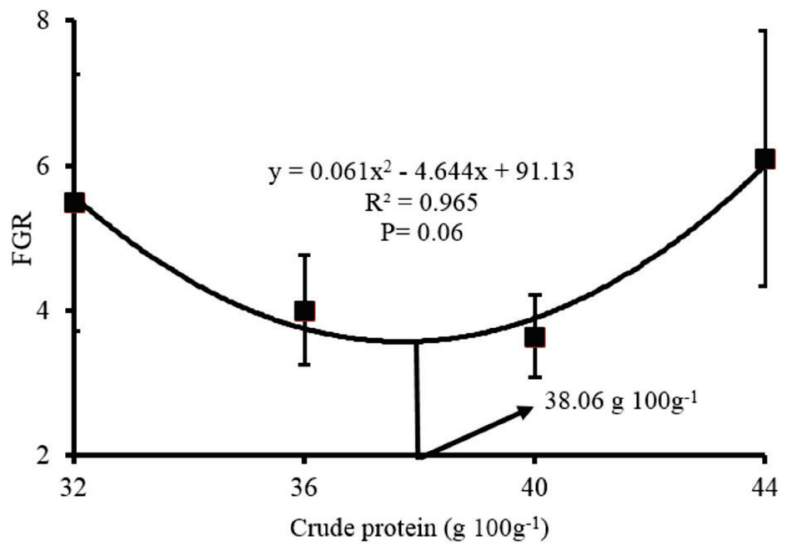

Figure 2: Polynomial regression of average feed:gain ratio (FGR) of juvenile mojarra (Diapterus rhombeus) fed with different crude protein levels in the diet.

The worst feed:gain ratio for these treatments might be associated with the fact that there is a significant difference between weight gain and no difference in feed consumption, i.e. the fish ingest similar quantities and use them differently. The energy:protein ratio in the diets varied. The best results occur in the ratio between 11 to $10: 1$, which may indicate the requirement of the species in the development phase.

The feed:gain ratio observed for mojarra in this study are superior to those found for cobia (Rachycentron canadum) (1.3 to 2.2) in cultivation systems on the open sea (Benetti et al., 2010), and it is important to consider that the experimental conditions of this work consisted of animals kept in a laboratory, which were captured in their natural environment, while for the cobia, the fact that fingerling production is already in progress decreases heterogeneity and their cultivation in open sea provides an environment closest to their natural environment, enhancing the performance of fish in cultivation systems.

Souza et al. (2011), while evaluating the protein requirement of the fat snook (Centropomus parallelus), verified a negative linear effect of an increased CP level on feed conversion, which suggests a greater efficiency in the use of feed at higher protein levels. Such positive effects are credited as resulting from increased levels of CP that improve the amino acid profile supplied to the fish. Similar results were observed by researchers working with other marine species such as the red hake, (Sciaenops ocellatus) (Jirsa; Davis; Arnold, 1997) and the Florida pompano (Trachinotus carolinus) (Lazo; Davis; Arnold, 1998). Results in which the level of 
crude protein did not influence feed conversion were obtained by Teixeira, Machado and Fracalossi (2010) and Signor et al. (2004) in studies with silver catfish and by Furuya et al. (2000) when assessing Nile tilapia fingerlings.

The protein efficiency ratio presented a quadratic response to treatments, increasing as they raised the levels of crude protein up to the estimated figure of $38.9{\mathrm{~g} 100 \mathrm{~g}^{-1}}^{-1}$ of $\mathrm{CP}$ in the feed, from that figure the variable began to decline (Figure 3).

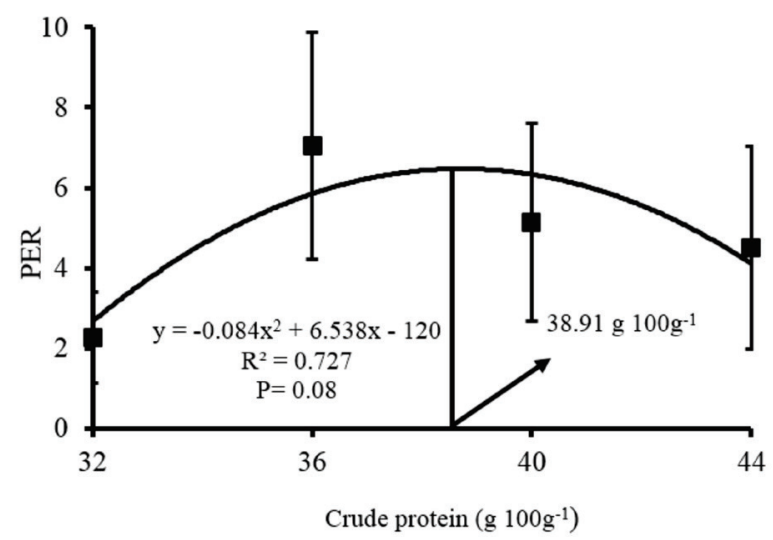

Figure 3: Polynomial regression of protein efficiency ratio (PER) in juvenile mojarra (Diapterus rhombeus) fed with different crude protein levels in the diet.

Whereas protein efficiency rate is an indicator of how the fish use consumed protein and how much excess protein can be used as an energy source (Millward, 1989),

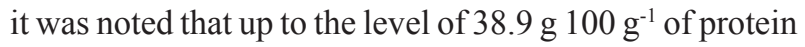
ingested, there was an improvement in conversion and growth at higher levels, the protein served to supply the energy needs or were not efficiently harnessed, resulting in a decrease in the animal's performance, indicating that the supply of protein at levels surplus to requirements makes it possible for just one part to be used for muscle tissue formation and growth and the remainder to be converted into energy (Winfree; Stickney, 1981; Millward, 1989, Nrc, 2011).

Dietary protein levels below the fish's requirement decreases its use efficiency. As the dietary nutrient level increases, it improves protein utilization and reaches an optimal level near the minimum required protein content, while an excess of this nutrient can reduce the efficiency of its use (Sampaio; Kubitza; Cyrino, 2000).

Another factor to be considered is that the quality of the supplied protein may influence animals' performance. Researchers working with silver catfish (Rhamdia quelen) and with the Brazilian tiger fish (Pseudoplatystoma corruscans) show that the activity of alkaline proteases (trypsin and chymotrypsin) may suffer a greater effect from the composition of the feed than simply by varying the amount of protein (Melo et al., 2002; Lundstedt; Melo; Moraes, 2004). In other words, if the provided protein is not of good quality, it will interfere in its use by the animal. Lazzari et al. (2010) observed that juvenile silver catfish had less alkaline protease activity (trypsin and chymotrypsin), causing a reduction in weight gain when fed with a high concentration of soybean meal in its feed composition.

There was no significant effect observed from feed protein levels on the body composition of juvenile mojarra at the end of the trial period (Table 4).

The results are in line with those from Duan et al. (2001), who studied the yellow croaker (Polyactis crocea). However, it is well known that the variation of protein content in feed can directly influence the performance and body composition of fish (Furuya et al., 2000, 2005, Botaro; Furuya; Silva, 2007).

Table 4: Proximate composition (g $100 \mathrm{~g}^{-1}$ ) of initial and final carcass in juvenile mojarra (Diapterus rhombeus), fed with different crude protein levels in the diet (on dry matter*).

\begin{tabular}{ccccccc}
\hline \multirow{2}{*}{ Variable } & \multicolumn{5}{c}{ Concentration of protein in diets $\left(\mathrm{g} 100 \mathrm{~g}^{-1}\right)$} & \multirow{2}{*}{ p value } \\
\cline { 2 - 5 } & Initial & 32 & 36 & 40 & 44 & \\
\hline Gross energy $\left(\mathrm{Kcal} \mathrm{kg}^{-1}\right)$ & 4053 & 4581 & 4675 & 4782 & 4531 & 0.28 \\
Ether extract & $22.9 \pm 0.5$ & $29.8 \pm 2.2$ & $27.6 \pm 2.9$ & $29.7 \pm 2.5$ & $30.5 \pm 4.4$ & 0.62 \\
Crude protein & $56.3 \pm 2.9$ & $56.4 \pm 1.4$ & $58.8 \pm 1.0$ & $57.8 \pm 1.4$ & $58.2 \pm 1.1$ & 0.09 \\
Dry matter & 23.92 & $23.4 \pm 3.2$ & $25.4 \pm 0.5$ & $22.8 \pm 2.1$ & $25.1 \pm 0.7$ & 0.48 \\
Ash & $16.5 \pm 0.6$ & $18.6 \pm 0.7$ & $18.7 \pm 1.0$ & $17.8 \pm 0.8$ & $18.8 \pm 5.6$ & 0.95 \\
\hline
\end{tabular}




\section{CONCLUSION}

Diet crude protein concentration between 38.1 and

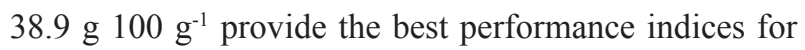
juvenile mojarra, Diapterus rhombeus.

\section{ACKNOWLEDGMENTS}

The authors would like to express their sincere thanks to Coordination for the Improvement of Higher Education Personnel - PROCAD-NF 2343/2008 (CAPES) and National Council of Technological and Scientific Development - 562040/2010-2 (CNPq) for the financing for this research project.

\section{REFERENCES}

AGUIRRE-LÉON, A.; DÍAZ-RUIZ, S. Size structure, gonadic development and diet of the fish Diapterus rhombeus (Gerreidae) in the Pom-Atasta fluvial-deltaic system, Campeche, Mexico. Revista de Biología Tropical, 54(2):599-611, 2006.

ASSOCIATION OF OFFICIAL ANALYTICAL CHEMISTS - AOAC. Oficial methods of Analysis of Association of Official Analytical Chemists.18.ed. Gaithersburg: Maryland, 2005. 1298p.

BENETTI, D. D. et al. Growth rates of cobia (Rachycentron canadum) cultured in open ocean submerged cages in the Caribbean. Aquaculture, 302:195-201, 2010.

BOMFIM, M. A. D.; LANNA, E. A. T.; DONZELE, J. L. Reduction of crude protein with amino acid supplementation, based on ideal protein concept, in diets for Nile tilapia fingerlings. Revista Brasileira de Zootecnia, 37(10):1713-1720, 2008.

BOTARO, D.; FURUYA, W. M.; SILVA, L. C. R. Dietary protein reduction based on ideal protein concept for Nile tilapia (Oreochromis niloticus) cultured in net pens. Revista Brasileira de Zootecnia, 36(3):517-525, 2007.

CHAVES, P. T. C.; OTTO, G. Biological aspects of Diapterus rhombeus (Cuvier) (Teleostei, Gerreidae) at Guaratuba Bay, Paraná, Brazil. Revista Brasileira de Zoologia, 15(2):289295, 1998.

COTAN, J. L. V.; LANNA, E. A. T.; BOMFIM, M. A. D. Dietary levels of digestible energy and crude protein for lambari tambiú fingerlings. Brazilian Journal of Animal Science, 35(3):634-640, 2006.
CYRINO, J. E. P. et al. Fish farming and the environment: The use of environmental friendly feeds in fish culture. Brazilian Journal of Animal Science, 39:68-87, 2010.

DUAN, Q. et al. Studies on the nutrition of the large yellow croaker, Pseudosciae nacrocea R. I: Growth response to graded levels of dietary protein and lipid. Aquactic Research, 32:46-52, 2001.

ELLIFF, C. I. et al. Population structure of caitipa mojarra (Diapterus rhombeus) in an estuarine system of southeastern Brazil. Boletim do Instituto de Pesca, 39(4):411-421, 2013.

FERNANDES, J. B. K.; CARNEIRO, D. J.; SAKAMURA, N. K. Sources and levels of crude protein in diets for pacu (Piaractus mesopotamicus) fingerlings. Revista Brasileira de Zootecnia, 30:617-626, 2001.

FERRARI, J. E. C. et al. Copper levels in Nile tilapia Oreochromis niloticus diets. Acta Scientiarum. Animal Sciences, 26:429-436, 2004

FURUYA, W. M. et al. Ideal protein concept for dietary protein reduction of juvenile Nile tilapia (Oreochromis niloticus). Revista Brasileira de Zootecnia, 34(5):14331441, 2005.

FURUYA, W. M. et al. Protein requirements for reversed fingerling Nile tilapia (Oreochromis niloticus). Revista Brasileira de Zootecnia, 29(6):1912-1917, 2000.

JIRSA, D. O.; DAVIS, D. A.; ARNOLD, C. R. Effects of dietary nutrient density on water quality and growth of red drum Sciaenops ocellatus in closed systems. Journal of the World Aquaculture Society, 28:68-78, 1997.

KAUSHIK, S. J. et al. Almost total replacement of fish meal by plant protein sources in the diet of a marine teleost, the European seabass, Dicentrarchus labrax. Aquaculture, 230:391-404, 2004.

LAZO, J. P.; DAVIS, D. A.; ARNOLD, C. R. The effects of dietary protein level on growth, feed efficiency and survival of juvenile Florida pompano (Trachinotus carolinus). Aquaculture, 169:225-232, 1998.

LAZZARI, R. et al. Protein sources and digestive enzyme activities in jundiá (Rhamdia quelen). Scientia Agricola, 67(3):259-266, 2010.

Performance and fillet composition of jundia (Rhamdia quelen) submitted to different diets in the rearing. Brazilian Journal of Veterinary and Animal Science, 60(2):477-484, 2008. 
LUNDSTEDT, L. M.; MELO, J. F. B.; MORAES, G. Digestive enzymes and metabolic profile of Pseudoplatystoma corruscans (Teleostei: Siluriformes) in response to diet composition. Comparative Biochemistry and Physiology, 137B:331339, 2004.

MABROUK, H. A.; NOUR, A. M. Assessment of apparent digestibility coefficients (ADCs \%) of some animal protein sources by gilthead sea bream (Sparus aurata). Egyptian Journal of Aquatic Research, 37(2):171-177, 2011.

MELO, J. F. B. et al. Development and body composition of south american catfish (Rhamdia quelen) fingerlings fed with differents lipid dietary sources. Ciência Rural, 32(2):323327, 2002.

MILLWARD, D. J. The nutritional regulation of muscle growth and protein turnover. Aquaculture, 79:1-28, 1989.

MOURA, G. S. et al. Performance and amylase activity in Nile tilapia submitted to different temperatures. Pesquisa Agropecuária Brasileira, 42(11):1609-1625, 2007.

NATIONAL RESEARCH COUNCIL - NRC. Nutrient requirements of fish and shrimp. Washington, D.C., 2011. 376p.

R DEVELOPMENT CORE TEAM (2011). R: A language and environment for statistical computing. R. Foundation for Statistical Computing, Vienna, Austria. ISBN 3-90005107-0. Available in: <http://www.R-project.org/>. Access in: 01 February 2015.

REFSTIE, S.; HELLAND, S. J.; STOREBAKKEN, T. Adaptation to soybean meal in diets for rainbow trout, Oncorhynchus mykiss. Aquaculture, 153:263-272. 1997.

REFSTIE, S.; STOREBAKKEN, T.; ROEM, A. J. Feed consumption and conversion in Atlantic salmon (Salmo salar) fed diets with fish meal, extracted soybean meal or soybean meal with reduced content of oligosaccharides, trypsin inhibitors, lectins and soya antigens. Aquaculture, 162:301-312, 1998.

SÁ, M. V. C.; FRACALOSSI, D. M. Dietary protein requirement and energy to protein ratio for piracanjuba (Brycon orbignyanus) fingerlings. Revista Brasileira de Zootecnia, 31(1):1-10, 2002.
SAMPAIO, A. M. B.; KUBITZA, F.; CYRINO, J. E. P. Energy: protein ratio and the nutrition of the peacock bass. Scientia Agrícola, 57(2):213-219, 2000.

SIGNOR, A. A. et al. Exigência de proteína bruta para alevinos de jundiá Rhamdia quelen. Revista Varia Scientia, 4(8):7989, 2004.

SILVA, J. F. et al. Purification and partial characterisation of a trypsin from the processing waste of the silver mojarra (Diapterus rhombeus). Food Chemistry, 129:777-782, 2011.

SOUZA, J. H. et al. Growth and economic performance of juvenile fat snook feddiets containing different protein levels. Pesquisa Agropecuária Brasileira, 46(2):190-195, 2011.

STECH, M. R.; CARNEIRO, D. J.; CARVALHO, M. R. B. Antinutritional factors and protein apparent digestibility coefficients of soybeans sources to pacu (Piaractus mesopotamicus). Acta Scientiarum. Animal Sciences, 32(3):255-262, 2010.

TEIXEIRA, B.; MACHADO, C. C.; FRACALOSSI, D. M. Dietary protein requirement of dourado (Salminus brasiliensis) fingerlings. Acta Scientiarum. Animal Sciences, 32(1):3338, 2010.

VIDALJUNIOR, M. V. et al. Levels of crude protein for tambaqui (Colossoma macropomum), in the phase of 30 to 250 grams: the tambaquis performance. Revista Brasileira de Zootecnia, 27(3):421-426, 1998.

WANG, F. et al. Growth, feed utilization and body composition of juvenile golden pompano Trachinotus ovatus fed at different dietary protein and lipid levels. Aquaculture Nutrition, 19:360-367, 2013.

WILSON, R. P. Amino acid requirements of finfish and crustaceans. In: D'MELLO, J. P. F. (Ed.). Amino Acids in Animal Nutrition. 2. ed. Wallingford: $C A B$ International, 2003. p.427-447.

WINFREE, R. A; STCKNEY, A. A. Effects of dietary protein and energy on growth, feed conversion efficiency and body composition of tilapia aurea. Journal of Nutrition, 111:1001-1012, 1981. 